CHANNEL AND BANK STABILITY OF BIG BLACK RIVER CANAL TRIBUTARY AT U.S. HIGHWAY 82 AT STEWART, MONTGOMERY COUNTY, MISSISSIPPI

By K. Van Wilson and D. Phil Turnipseed

U.S. GEOLOGICAL SURVEY

Open-File Report 89-35

Prepared in cooperation with the

MISSISSIPPI STATE HIGHWAY DEPARTMENT

Jackson, Mississippi

1989 


\section{DEPARTMENT OF THE INTERIOR \\ DONALD PAUL HODEL, Secretary \\ U.S. GEOLOGICAL SURVEY \\ Dallas L. Peck, Director}

For additional information write to:

District Chief U.S. Geological Survey 100 W. Capitol Street Suite 710, Federal Building Jackson, Mississippi 39269
Copies of this report can be purchased from:

U.S. Geological Survey

Books and Open-File Reports Section Building 810

Federal Center, Box 25425

Denver, Colorado 80225 


\section{CONTENTS}

Page

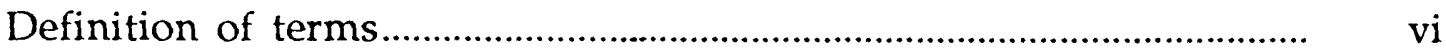

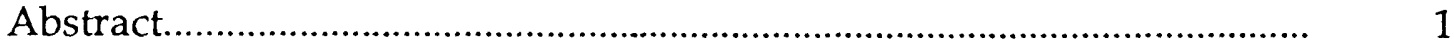

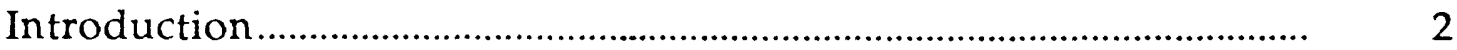

Purpose and scope .............................................................................. 2

General description of Big Black River Canal tributary................... 2

Channel modifications to Big Black River .......................................... 2

Acknowledgments................................................................................. 2

Channel bed...................................................................................................

Botanical evidence of degradation..........................................................

Degradation analysis............................................................................... 4

Channel banks...........................................................................................

Botanical evidence of widening...............................................................

Stability analysis..........................................................................................

Widening analysis................................................................................... 10

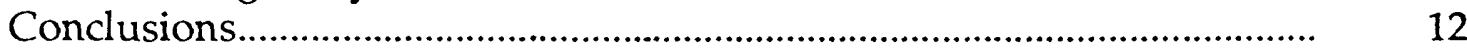

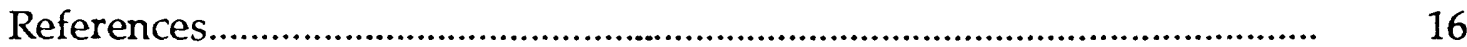

\section{ILLUSTRATIONS}

Figure 1. Map showing the location of Big Black River Canal tributary at U.S. Highway 82 at Stewart, Mississippi

2. Channel-bed profiles for Big Black River Canal tributary in the vicinity of U.S. Highway 82 at Stewart, Mississippi

3. Estimated patterns of degradation on Big Black River Canal tributary at U.S. Highway 82 at Stewart, Mississippi, and on Big Black River Canal at the mouth of the tributary.

4. Cross section showing critical failure surfaces for channel banks on Big Black River Canal tributary 100 feet downstream of U.S. Highway 82 at Stewart, Mississippi.

5. Existing channel cross section showing near-future widening for Big Black River Canal tributary, 75 feet upstream of U.S. Highway 82 at Stewart, Mississippi.

6. Existing channel cross section showing near-future widening for Big Black River Canal tributary, 100 feet downstream of U.S. Highway 82 at Stewart, Mississippi.........

7. Existing channel cross section showing near-future widening for Big Black River Canal tributary, 500 feet downstream of U.S. Highway 82 at Stewart, Mississippi. 


\section{TABLES}

Page

Table 1. Channel-bed degradation on Big Black River Canal at the mouth of the tributary

2. Channel-bed degradation on Big Black River Canal tributary at U.S. Highway 82 at Stewart, Mississippi

7

3. Shear-strength properties and bulk unit weights of soils as determined from borehole tests............................................... 


\section{CONVERSION FACTORS}

For readers who may prefer to use the metric (International System) of units rather than the inch-pound units used herein, the conversion factors are listed below:

$\begin{array}{lcll}\text { Multiply inch-pound unit } & \text { by } & \text { To obtain metric unit } \\ \text { foot per second }(\mathrm{ft} / \mathrm{s}) & & \\ \text { cubic foot per second }\left(\mathrm{ft}^{3} / \mathrm{s}\right) & 0.3048 & \text { meter per second } \\ \text { foot }(\mathrm{ft}) & 0.02832 & \text { cubic meter per second } \\ \text { foot per mile }(\mathrm{ft} / \mathrm{mi}) & 0.3048 & \text { meter } \\ \text { square foot }\left(\mathrm{ft}^{2}\right) & 0.018939 & \text { meter per kilometer } \\ \text { pounds per square foot }\left(\mathrm{lb} / \mathrm{ft}^{2}\right) & 0.09290 & \text { square meter } \\ \text { pounds per cubic foot }\left(\mathrm{lb} / \mathrm{ft}^{3}\right) & 157.88 & \text { newtons per square meter } \\ \text { mile }(\mathrm{mi}) & 1.609 & \text { newtons per cubic meter } \\ \text { square mile }\left(\mathrm{mi}^{2}\right) & 2.590 & \text { kilometer } & \text { square kilometer }\end{array}$

Sea Level: In this report, "sea level" refers to the National Geodetic Vertical Datum of 1929 (NGVD of 1929) - a datum derived from a general adjustment of the first-order level nets of both the United States and Canada, formerly called "Sea Level Datum of 1929." Mississippi State Highway Department Datum is to NGVD of 1929. 


\section{DEFINITION OF TERMS}

Terms used in this report are defined below.

Angle of internal friction -angle of the plane of contact of soil particles with the horizontal at the point of sliding (shearing); angle whose tangent is the coefficient of friction between the soil particles (Cernica, 1982).

Cohesion -attraction of adsorbed water and soil particles that produce a body, which holds together but deforms plastically at varying water contents (Sowers, 1979).

Critical bank height -height of channel bank above which failure can be expected, produced by an increased height (channel-bed degradation) or bank angle (over steepening through erosion) (Thorne and others, 1981).

Channel-bed degradation -headward erosion of the channel bed usually caused by increases in downstream channel gradient and cross-sectional area by man (Simon and Hupp, 1986b).

Dry bulk unit weight -ratio of the weight of the soil solids to the volume of the soil sample (Das, 1984).

Factor of safety -ratio of the resisting force (shear strength of the soil) to the driving force (weight of the soil). If the resisting force is less than the driving force, the factor of safety is less than 1.0, and therefore, failure occurs (Huang, 1983).

Failure-block widths -the measured width of the failure block or the distance between affected stems of woody plants growing in bank material that has failed and fallen down slope and the existing top-bank edge (Hupp. 1987).

lowa Borehole Shear Test (BST) -direct measure of shear strength of fine- to medium-grained soils insitu (from inside a borehole) (Handy, 1981).
Knickpoint -an abrupt change in channelbed elevation along a reach of channel relative to the upstream or downstream direction.

Moisture content -ratio of the weight of the water present to the weight of the soil solids (Das, 1984).

Rotational failure -landslide along a surface of rupture that is concave upward. The exposed cracks are concentric in plan and concave toward the direction of movement (Huang, 1983).

Shear strength -capacity of a soil to resist shear; in terms of effective stress, it can be given by the equation:

where:

$$
s^{\prime}=c^{\prime}+\sigma^{\prime} \tan \phi^{\prime}
$$

$\sigma^{\prime}=$ effective normal stress on plane of shear

$c^{\prime}=$ cohesion or apparent cohesion of the soil; and

$\phi^{\prime}=$ angle of internal friction.

(Das, 1984).

Slough-line angle -angle attained by projecting the slope of failed blocks of soil mass (which represents a temporary angle of stability) to its intersection with the top of channel bank (flood-plain level). It is used to determine short-term (10-20 years) bank widening (Simon and Hupp, 1986a).

Temporary angle of stability the angle from the horizontal extended from the toe to the top of bank in which that bank at that given height is the most stable. It can be estimated by averaging the existing bank angle with the angle of internal friction of the bank material. (Spangler and Handy, 1973).

Triaxial test -shear strength value obtained in the laboratory from a cored soil sample of either sand or clay which is taken from the field (Sowers, 1979). 


\title{
CHANNEL AND BANK STABILITY \\ OF BIG BLACK RIVER CANAL TRIBUTARY AT U.S. HIGHWAY 82 AT STEWART, MONTGOMERY COUNTY, MISSISSIPPI
}

\author{
by K. Van Wilson and D. Phil Turnipseed
}

\begin{abstract}
The channel of Big Black River Canal tributary at the site of the proposed reconstruction of the U.S. Highway 82 crossing at Stewart, Mississippi, has degraded about $8 \% / 2$ feet since the construction of the Big Black River Canal in about 1928. Channel degradation at the mouth of the tributary has totaled about 10 feet during the period. Several bank failures in the vicinity of the highway crossing have occurred within the past 5 years and the channel continues to degrade and widen in response to the degradation of Big Black River Canal that was partially excavated in about 1928 and further modified in 1939.

Rates of channel degradation and widening--as determined from channel descriptions, discussions with local residents, and botanical evidence along the banks--were used in conjunction with soil properties to estimate probable future channel degradation and widening through the year 2010. By assuming that channel-bed elevations can be expressed as a power function with time, additional channel degradation through the year 2010 is expected to be about $1 / 2$ foot at the highway crossing and at the mouth of the tributary. The channel top-bank width is expected to increase about 20 feet just downstream of the highway crossing in the next 5 to 10 years, based on the assumption that the present rate of widening continues. These projections are based on the assumption that no additional channel modifications and no unusually large and destructive flooding will occur by the year 2010 .
\end{abstract}




\section{INTRODUCTION}

The Mississippi State Highway Department proposes to reconstruct the U.S. Highway 82 crossing of Big Black River Canal tributary at Stewart, Mississippi (fig. 1). Because channel degradation and bank widening have recently occurred in the lower reach of Big Black River Canal tributary, the U.S. Geological Survey, in cooperation with the Mississippi State Highway Department, began a study of channel and bank stability at this site.

\section{Purpose and Scope}

The purpose of this report is to describe existing channel and bank conditions and present the results of a study to determine the potential for near-future degradation and widening for Big Black River Canal tributary at U.S. Highway 82 at Stewart, Miss. Existing channel and bank conditions are described based on making field observations, determining ages and types of trees on the channel banks, and obtaining bulk unit weights and shearstrength properties of bank material to evaluate the potential for bank failures. The potential for near-future degradation is estimated by using a power function of past channel-bed elevations with time for Big Black River Canal tributary at U.S. Highway 82 and for Big Black River Canal at the mouth of the tributary. The potential for widening is estimated by using existing channel geometry and shear-strength properties of the bank material. The report is the first in a series of similar reports for selected stream crossings in Mississippi.

\section{General Description of Big Black River Canal Tributary}

Big Black River Canal tributary is located in the North-Central Plateau, East Gulf Coastal Plain physiographic region. The drainage area of Big Black River Canal tributary at U.S. Highway
82 is $1.35 \mathrm{mi}^{2}$ (square miles), and the length of the channel upstream is about $3.0 \mathrm{mi}$ (miles). Average channel and valley slopes in the vicinity are about 18 and $21 \mathrm{ft} / \mathrm{mi}$ (feet per mile), respectively. The tributary flows into Big Black River Canal about $0.7 \mathrm{mi}$ downstream of the U.S. Highway 82 crossing; therefore, if the canal degrades, the tributary eventually degrades.

The channel of Big Black River Canal tributary in the vicinity of U.S. Highway 82 is incised into a layer of hard clay. Soil borings indicate that this clay strata has interbedded sand layers.

\section{Channel Modifications to Big Black River}

According to local residents, in about 1928, the Big Black Drainage District No. 1 excavated a canal about $14 \mathrm{mi}$ long in the right (north) side of the Big Black River flood plain between Tomnolen and a point near Kilmichael. This canal flows into Big Black River about $8.1 \mathrm{mi}$ downstream from the junction of Big Black River Canal and the Big Black River Canal tributary. At about the same time, the Webster-Choctaw Drainage District excavated a canal upstream from Sapa. In 1939, the U.S. Army Corps of Engineers excavated a canal in the 8-mi reach connecting the two Drainage District canals (fig. 1). Additional drainage modifications made by the Corps of Engineers at that time included construction of 43 channel cutoffs and clearing and snagging of the river downstream of the canals (U.S. Army Corps of Engineers, 1946). No additional channel modifications of Big Black River are planned (J. Meador, U.S. Army Corps of Engineers, oral commun., 1988).

\section{Acknowledgments}

The authors are indebted to members of the Mississippi State Highway Department who provided bridge inspection records and assisted in the analysis of soil samples in the State soils laboratory. The authors also acknowledge the valuable guidance and 


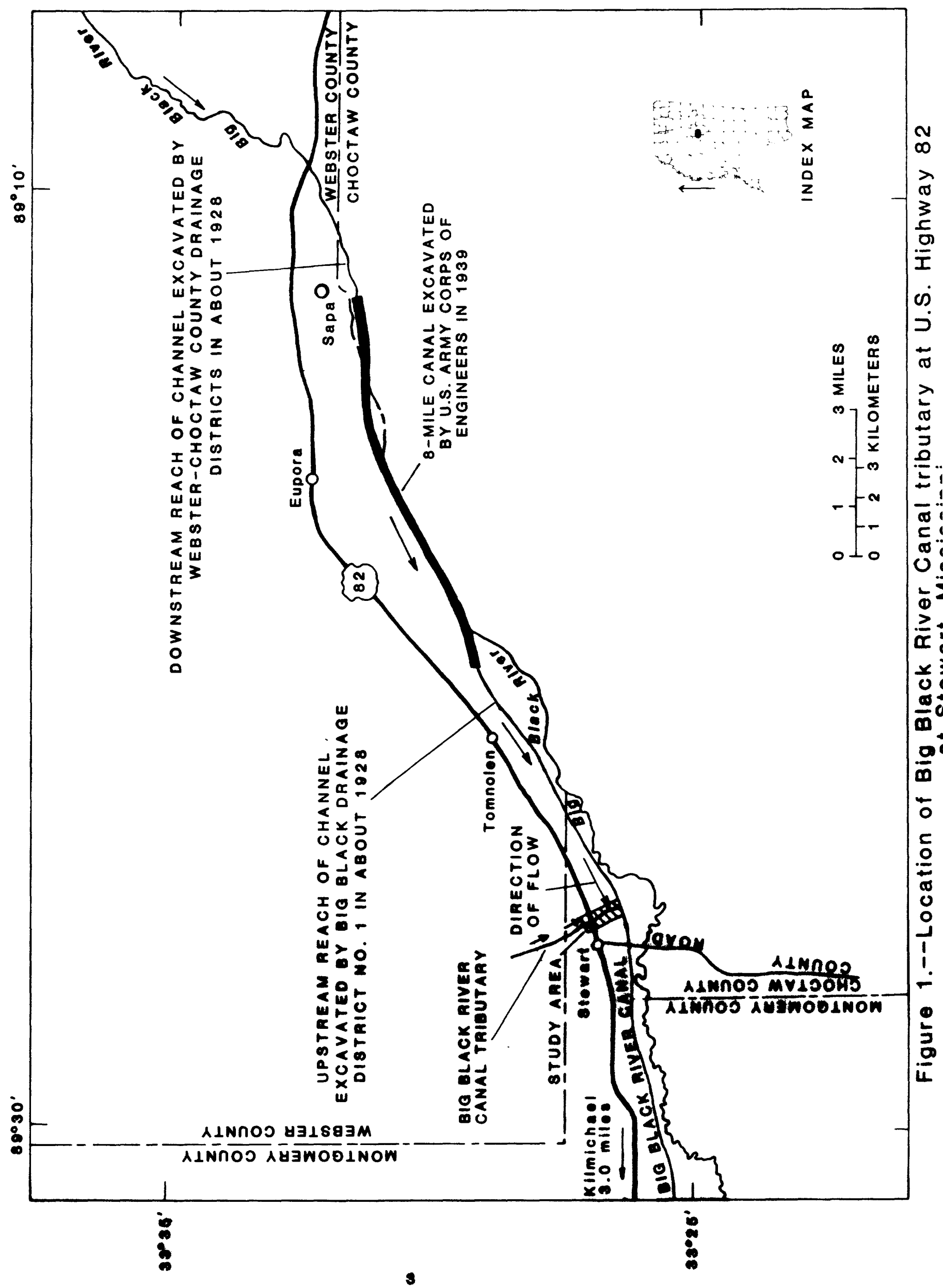


technical assistance provided by U.S. Geological Survey employees Andrew Simon, Cliff R. Hupp, and Bradley A. Bryan in Nashville, Tenn.

\section{CHANNEL BED}

\section{Botanical Evidence of Degradation}

Trees growing below top banks can indicate rates of aggradation or degradation through measurement of the thickness of sediment burial, or exhumation, from the root collar, which is established at the ground surface during germination (Simon and Hupp, 1986a). Exhumation from the root collar of trees growing below top banks indicated that the elevation of the channel bed near the highway crossing was about $336 \mathrm{ft}$ (feet) above sea level (about $8 \mathrm{ft}$ above the existing channel bed) prior to substantial degradation. Root-collar botanical evidence also indicated that the channel bed at the mouth of the tributary prior to substantial degradation was about $10 \mathrm{ft}$ above the existing channel bed (fig. 2).

\section{Degradation Analysis}

Channel degradation on an alluvial stream undergoing morphologic change in response to channel modifications generally starts at a high rate and diminishes with time. Studies of channel degradation on alluvial streams in west Tennessee have shown that channel-bed elevation can be expressed as a power function with time (Simon and Hupp, 1986b), in the general form:

$$
E=\mathbf{a} \cdot \mathbf{t}^{\mathbf{b}}
$$

where

$\mathbf{E}=$ elevation of the channel bed, in feet above sea level;

$a=$ regression constant indicative of channel-bed elevation prior to the onset of channel-bed degradation in response to channel modification, in feet above sea level;

$$
\begin{aligned}
& \mathbf{b}= \text { regression coefficient, indicative } \\
& \text { of the rate of degradation; and } \\
& \mathbf{t}= \text { time, in years, since beginning of } \\
& \text { the channel-bed degradation } \\
& \text { process, }(t=1 \text { during the first } \\
& \text { year of channel adjustment). }
\end{aligned}
$$

Values of $\mathbf{a}$ and $\mathbf{b}$ in equation 1 will change if datums other than sea level for the channel-bed elevations (E) are used. If the datum used is below sea level datum, the value of a will decrease but the absolute value of $b$ will increase. If the datum is above sea level datum, the value of a will increase, but the absolute value of $\mathbf{b}$ will decrease. Also, by varying the datum, an imposed logarithmic offset for the log-linear relation will change; thus, in some cases, improving or worsening the log-linear statistical fit of the data points. In the Tennessee studies, the effects of channel-bed elevations on degradation trends were analyzed by varying the datum of the study sites. The analysis indicated no significant effects on the degradation trends (Andrew Simon, U.S. Geological Survey, oral commun., 1988).

It is assumed that the general form of equation 1 is applicable for estimating channel-bed degradation in the near future (by year 2010) on Big Black River Canal and Big Black River Canal tributary. The datums for both streams were varied and no significant effects were observed in estimating channel-bed degradation in the near future. Channelbed degradation processes in the past are assumed to be representative of those in the near future without accounting for additional channel modifications or unusually large destructive flooding that could begin other channel-adjustment processes.

The channel-bed elevations used in these analyses were obtained from surveys and inspections made by the Mississippi State Highway Department, the U.S. Army Corps of Engineers, and the U.S. Geological Survey. Some changes in channel-bed elevations may not be indicative of actual change, but rather of error involved in comparing the different survey measurements. The 


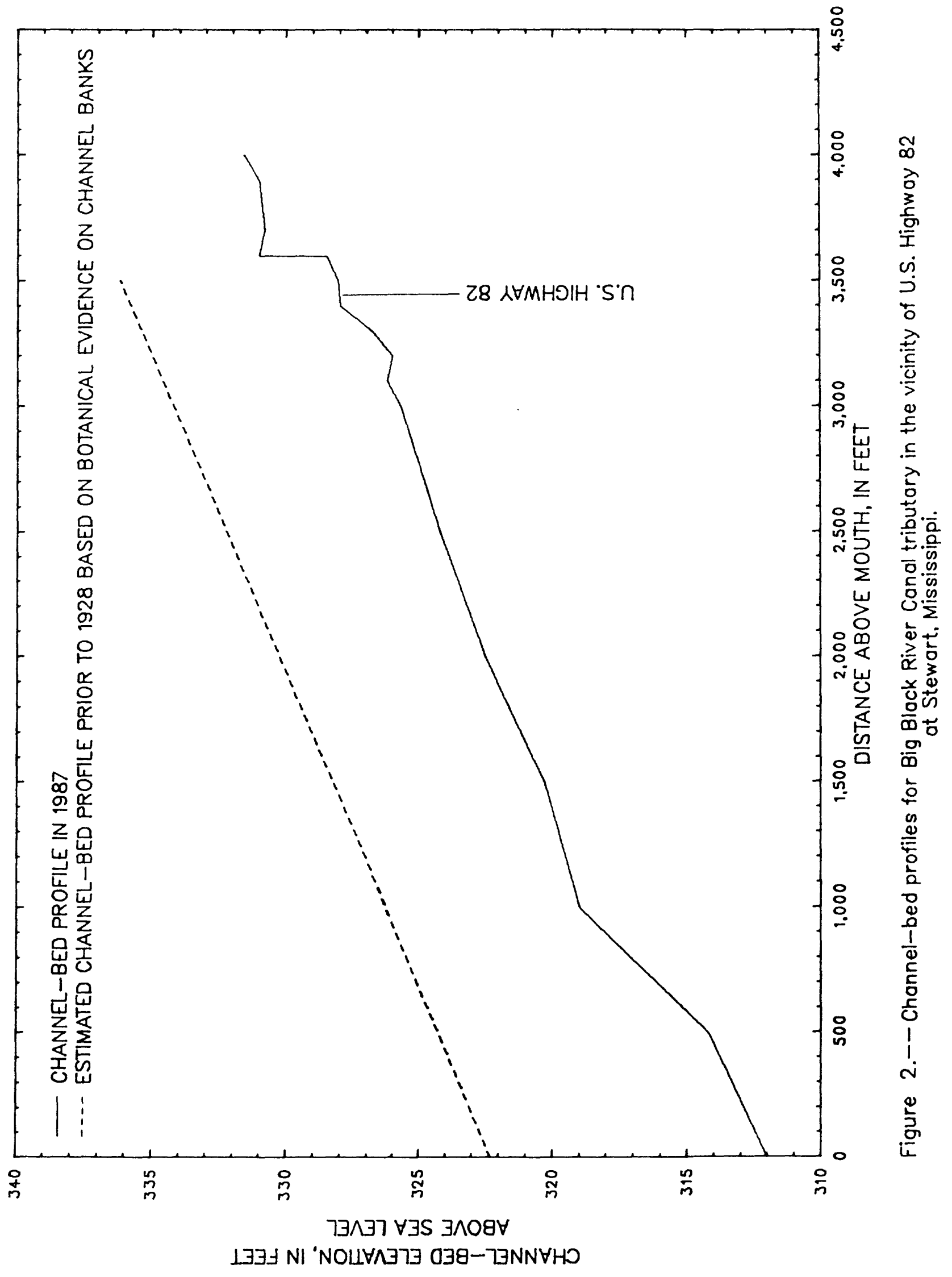


channel-bed elevations used to analyze degradation were obtained at bridges, but there was no significant evidence of localized scour. Localized scour occurs when flow velocities are increased for a short distance upstream and downstream from a bridge. This is due to the waterway area being substantially reduced by bridge-approach embankments, piers, and other obstructions. Localized scour would be an additional scour to the ongoing degradation process and, therefore, would not be representative of the selected reaches of channels studied.

Available channel-bed elevations determined in 1939, 1964, and 1987 at the county road crossing of Big Black River
Canal near Stewart were transferred 0.7 mi upstream to the junction of the canal and the tributary, based on the canal slope of about $2.5 \mathrm{ft} / \mathrm{mi}$ (fig. 1). This was based on the assumption that the rate of degradation of the channel bed of the canal is approximately the same at the mouth of the tributary and at the county road. A log-linear regression of the three transferred channel-bed elevations with their respective times was used to develop a channel-bed degradation equation for the canal at the mouth of the tributary $\left(E=323.3 \cdot t^{-0.00928}\right.$, where $t$ is time, in years since 1928). The transferred channel-bed elevations and projected channel-bed elevations through the year 2010 are presented in table 1.

Table 1.--Channel-bed degradation on Big Black River Canal at the mouth of the tributary

\begin{tabular}{|c|c|c|c|}
\hline Year & $\begin{array}{l}\text { Time, } t \\
\text { (years) }\end{array}$ & $\begin{array}{c}\text { Channel-bed elevation, E } \\
\text { (feet) }\end{array}$ & $\begin{array}{c}\text { Total } \\
\begin{array}{c}\text { degradation since } 1928 \\
\text { (feet) }\end{array}\end{array}$ \\
\hline 1928 & 1 & $1_{323.3}$ & 0.0 \\
\hline 1939 & 12 & 2315.8 & 7.5 \\
\hline 1964 & 37 & 2312.9 & 10.4 \\
\hline 1987 & 60 & 2311.0 & 12.3 \\
\hline 1990 & 63 & ${ }^{1} 311.1$ & 12.2 \\
\hline 1995 & 68 & 1310.9 & 12.4 \\
\hline 2000 & 73 & ${ }^{1} 310.7$ & 12.6 \\
\hline 2005 & 78 & ${ }^{1} 310.5$ & 12.8 \\
\hline 2010 & 83 & 1310.3 & 13.0 \\
\hline
\end{tabular}


The channel modifications to Big Black River in 1939 apparently did not disrupt the channel-bed degradation process on Big Black River Canal that began in about 1928 when the canal was originally excavated. The reason for this could be that the channel modifications of 1939 were substantial distances upstream and downstream from the study area.

A log-linear regression of six channelbed elevations from field surveys between 1936 and 1987 with their respective times was used to develop a channel-bed degradation equation for Big Black River Canal tributary at U.S. Highway 82 $\left(E=336.1 \cdot t^{-0.00620}\right.$, where $t$ is time, in years since 1936). It is uncertain when degradation began at U.S. Highway 82 . Relations of the channel-bed elevations with their respective times were developed by varying the beginning year between 1928 (when degradation began on the canal) and 1936. The best statistical fit was with time beginning in the year 1936, which indicates that the effects of degradation on the canal took about 8 years to progress upstream to the U.S. Highway 82 crossing. The resulting difference in channel-bed elevation from 1936 to 1987 agreed closely with field estimates of channel-bed degradation by use of botanical evidence. Channel-bed elevations determined from field surveys and projected channel-bed elevations through the year 2010 are presented in table 2 .

Table 2.--Channel-bed degradation on Big Black River Canal tributary at U.S. Highway 82 at Stewart, Mississippi

\begin{tabular}{lccc}
\hline Year & $\begin{array}{c}\text { Time, } t \\
\text { (years) }\end{array}$ & $\begin{array}{c}\text { Channel-bed elevation, E } \\
\text { (feet) }\end{array}$ & $\begin{array}{c}\text { Total } \\
\text { degradation since 1936 } \\
\text { (feet) }\end{array}$ \\
\hline & & 336.2 & \\
1936 & 1 & 333.7 & 0.0 \\
1938 & 3 & 330.2 & 2.5 \\
1954 & 19 & 329.2 & 6.0 \\
1963 & 28 & 328.1 & 7.0 \\
1986 & 51 & 327.9 & 8.1 \\
1987 & 52 & 1327.9 & 8.3 \\
1990 & 55 & 1327.7 & 8.3 \\
1995 & 60 & 1327.5 & 8.5 \\
2000 & 65 & 1327.4 & 8.7 \\
2005 & 70 & 1327.2 & 8.8 \\
2010 & 75 & & 9.0 \\
& & & \\
\hline
\end{tabular}

${ }^{1}$ Estimated using Regression Equation $E=336.1 \cdot t^{-0.00620}$, number of observations $=6$, coefficient of determination $=0.999$ 
A plot of the measured and regressionestimated channel-bed elevations as a function of time (fig. 3) indicates that near maximum degradation has occurred on the canal at the mouth of the tributary and on the tributary in the vicinity of U.S. Highway 82. About $12 y / 2 \mathrm{ft}$ of degradation has occurred on Big Black River Canal and about $81 / 2 \mathrm{ft}$ of degradation has occurred on the tributary. Further degradation through the year 2010 could reasonably be expected to be about $1 / 2 \mathrm{ft}$ on the Big Black River Canal and on the tributary.

\section{CHANNEL BANKS}

\section{Botanical Evidence of Widening}

Bank failures along unstable reaches may kill, tilt, or scar existing woody plants, and they create fresh surfaces upon which plants may become established. Scars and sprouts from parental stems of tilted plants yield accurate (within 1 year, often within one season) dates of bank failure (Sigafoos, 1964).

Eccentric growth, resulting in anomalous tree-ring series, occurs when the stem is inclined. This type of growth is easily determined from cross sections where concentric ring formation abruptly shifts to the eccentric because ring width is greater in the upslope direction than it is downslope. Eccentric ring patterns yield highly accurate dates, usually accurate within one season, of tilting. Dating of stems that have establshed on disturbed surfaces yields minimum ages for the surfaces (Simon and Hupp, 1986a).

Trees growing on unstable bank surfaces along Big Black River Canal tributary near U.S. Highway 82 show the effects of active bank sloughing in their stem morphology, anatomy, and ages. Channel banks on both sides of the stream downstream from the bridge are sloughing by rotational failures. Botanical data were collected by taking cross sections of sprouts from tilted trees (such as sweetgum, osage orange, and winged elm) to determine the ages of the sprouts and by measuring bank failureblock widths. These data indicate that on the left (east) bank, a $21 / 2$-ft-wide bank failure occurred in 1983-84 and a 3to 4-ft-wide failure occurred in 1984-85. On the right (west) bank, a 3-ft-wide failure occurred in 1985-86 and a 3- to 4$\mathrm{ft}$-wide failure, about $35 \mathrm{ft}$ long, occurred in 1987. Most of the bank failures appear to have occurred during the past 5 years, and the banks are retreating at an average rate of about $2 \% \mathrm{ft} / \mathrm{yr}$ (feet per year). This indicates that the critical bank height has been exceeded in this reach in recent years. About $50 \mathrm{ft}$ upstream from the bridge there is a $21 / 2-\mathrm{ft}$ knickpoint in the channel. Upstream from this knickpoint, only about 10 percent of the banks have sloughed in about the last 25 years. This was determined from banks on both sides of the stream being strongly armored with trees about 25 years old on the average (one was cored and determined to be 28 years old). It should be noted that botanical evidence of previous bank failures may have been obscured with time and (or) by succeeding large floods (Simon and Hupp, 1986a).

\section{Stability Analysis}

Shear-strength properties of the channel banks were determined on the right (west) bank of Big Black River Canal tributary about $100 \mathrm{ft}$ downstream of U.S. Highway 82 with an lowa borehole shear tester ${ }^{1}$ (BST) (Handy and Fox, 1967). Shear-strength properties and dry bulk-unit weights of soils obtained at the site are given in table 3. The average moisture content of the soils was about 16 percent.

Shear-strength data obtained using the BST compared reasonably well with the results of triaxial shear-strength tests that were made by the Mississippi

\footnotetext{
${ }^{1}$ The use of trade or product names in this report is for identification purposes only, and does not constitute endorsement by the U.S. Geological Survey.
} 


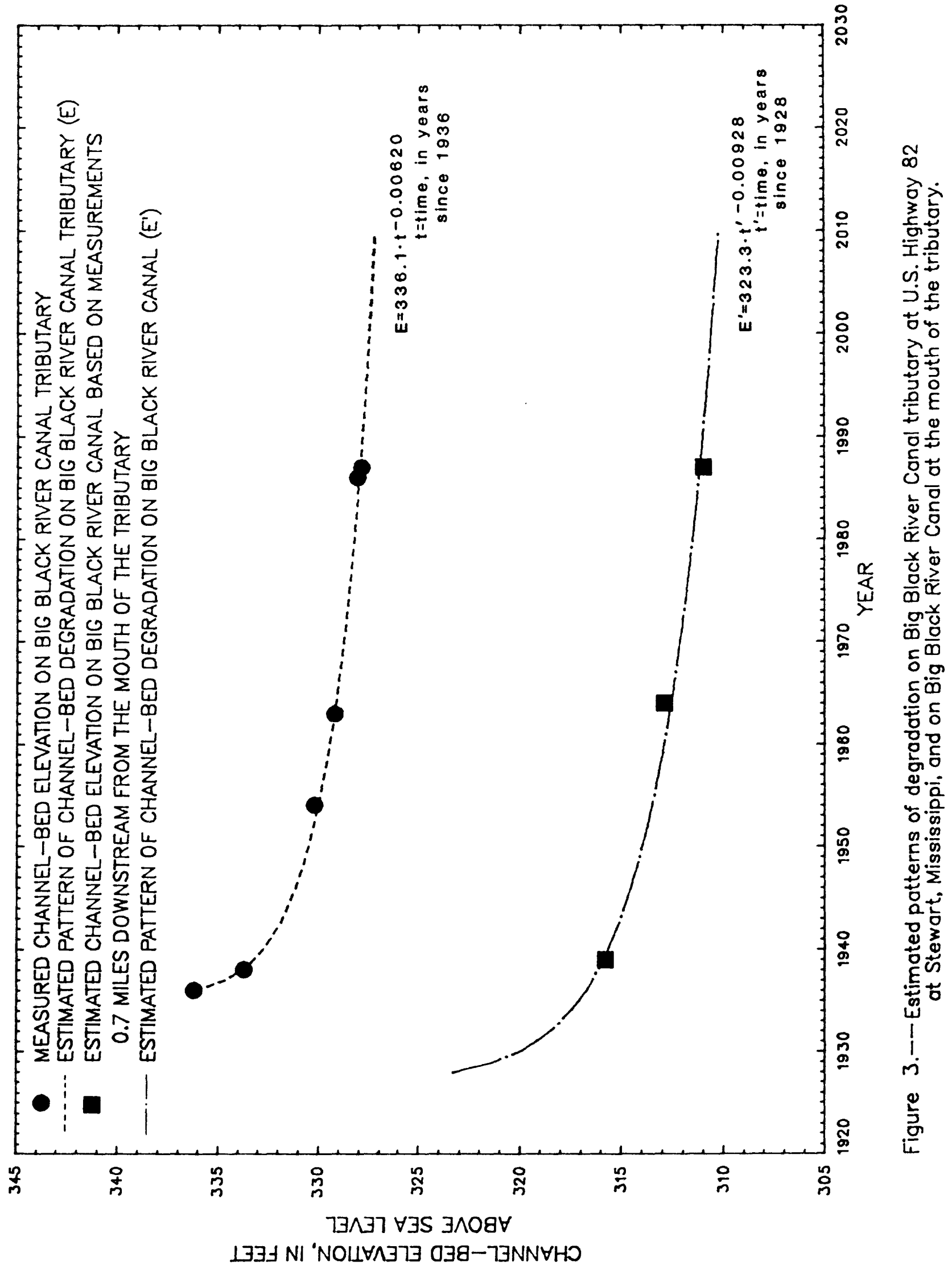


Table 3.--Shear-strength properties and bulk unit weights of soils as determined from borehole tests

[ft, feet; $\mathrm{lb} / \mathrm{ft}^{2}$, pounds per square foot; $\mathrm{lb} / \mathrm{ft}^{3}$, pounds per cubic foot]

\begin{tabular}{|c|c|c|c|c|}
\hline $\begin{array}{l}\text { General } \\
\text { soil description }\end{array}$ & $\begin{array}{c}\text { Bore hole } \\
\text { depth } \\
(\mathrm{ft})\end{array}$ & $\begin{array}{c}\text { Cohesion } \\
\left(\mathrm{lb} / \mathrm{ft}^{2}\right)\end{array}$ & $\begin{array}{c}\text { Angle of } \\
\text { internal } \\
\text { friction } \\
\text { (degrees) }\end{array}$ & $\begin{array}{c}\text { Dry } \\
\text { bulk unit } \\
\text { weight } \\
\left(\mathrm{lb} / \mathrm{ft}^{3}\right) \\
\end{array}$ \\
\hline Brown, clayey silt & $0-4$ & 63 & 37.5 & 92 \\
\hline Gray, sandy silt & $4-9$ & 60 & 37.0 & 110 \\
\hline $\begin{array}{l}\text { Brownish-gray, } \\
\text { sandy-silty clay }\end{array}$ & $9-11$ & 230 & 34.7 & 116 \\
\hline $\begin{array}{l}\text { Brownish-gray, } \\
\text { silty sand }\end{array}$ & $11-14$ & 0 & 32.9 & 110 \\
\hline
\end{tabular}

State Highway Department. BST results for individual soil strata were used in stability analyses.

Factors of safety for rotational bank failures for various degrees of bank saturation were determined by using shear-strength properties and bulk unit weights of the bank material at a typical cross section just downstream from the U.S. Highway 82 crossing. An iterative search to obtain the minimum factor of safety for each degree of bank saturation analyzed was done using the computer program REAME (Rotational Equilibrium Analysis of Multilayered Embankments) developed by Huang (1983). The factor of safety is the ratio of the resisting force (shear-strength of the bank material) to the driving force (weight of the bank material). Therefore, if the resisting force is equal to the driving force then the factor of safety is 1.0. Theoretically, when the factor of safety is less than 1.0, failure occurs, and when it is greater than 1.0, failure does not occur. This is based on the assumption that all the forces are accounted for. A factor of safety of at least 1.5 is usually used in design.

Factors of safety were less than 1.0 at all levels of saturation tested, indicating the banks of the tributary just downstream from the U.S. Highway 82 crossing are unstable. The critical rotational failure surfaces with their respective factors of safety for $0-, 25-$, and 50 -percent bank saturated conditions are shown in figure 4 . Note that the width of the failure-block surface at the top of the bank is about $2 \frac{1}{2} \mathrm{ft}$ for the 0 -percent bank saturation condition and about $1 \mathrm{ft}$ for the 25 - to 50-percent saturation condition. Therefore, this indicates that the next bank failure will most likely have a failure-block width from 1 to $2 \frac{1}{2} \mathrm{ft}$, depending on the percentage of bank saturation. Similar or wider failureblock widths were observed in the field. The width of the failure-block and the factor of safety decrease as bank saturation is increased because the driving force (weight of the bank material) is being increased.

\section{Widening Analysis}

Estimates of near-future (10 to 20 years) bank widening can be obtained by projecting the streambank slough-line angle on a plotted cross section (Simon and Hupp, 1986a). Extension of the slough line was not used at Big Black River Canal tributary, however, because the banks downstream of the U.S. Highway 82 bridge are unstable and the slough lines at the site are not well established. A temporary angle of 


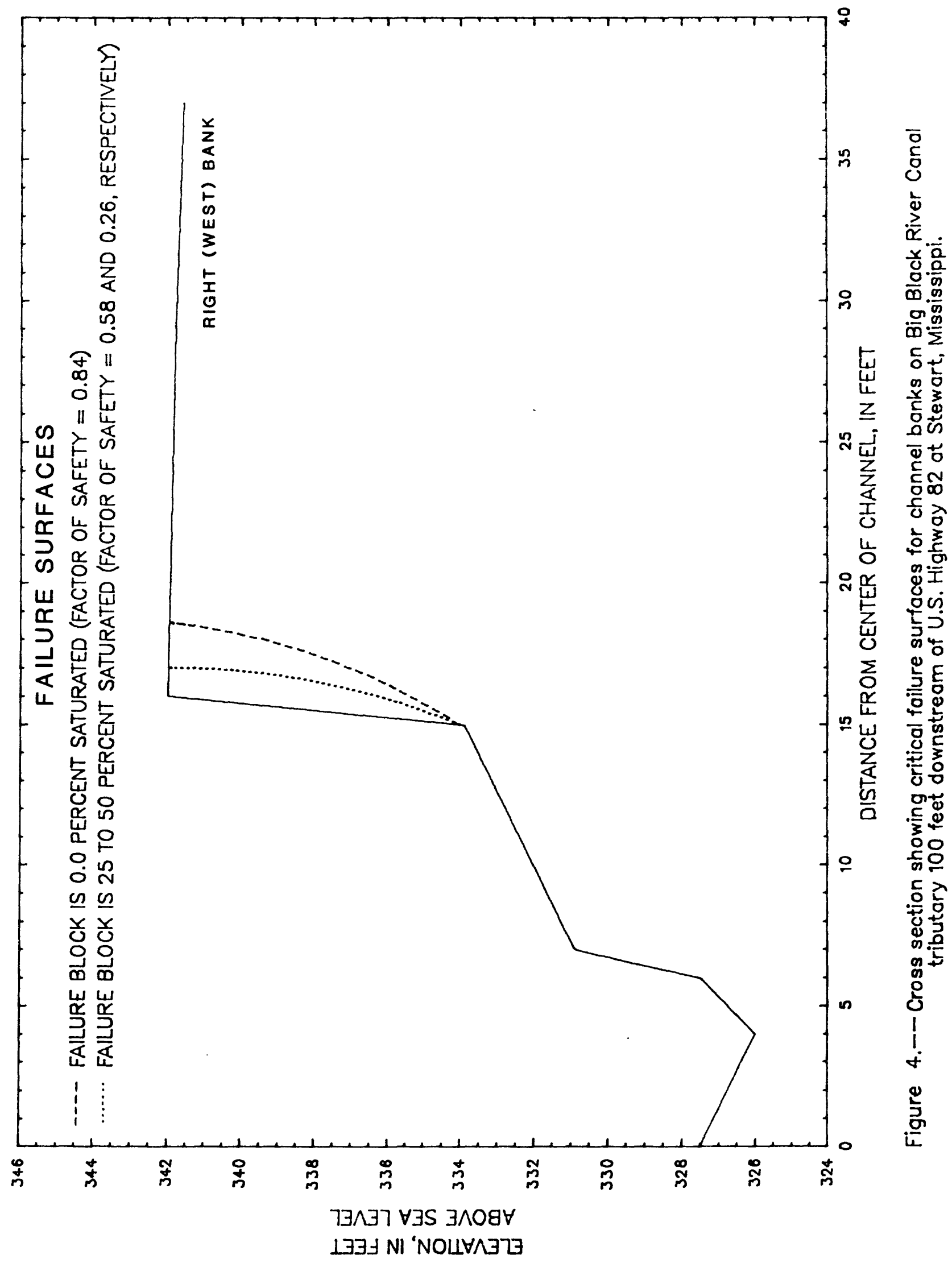


stability was estimated for each bank in each available channel cross section by averaging the existing bank angle and the angle of internal friction of the bank material, a technique developed by Spangler and Handy (1973). Estimates of near-future bank widening upstream of the bridge were made by extending the temporary angle of stability (fig. 5). Estimates of near-future bank widening downstream of the bridge were made by extending the angle of internal friction (figs. 6, 7). The temporary angle of stability was not used downstream of the bridge because the existing banks were unstable and the bank angles were not representative. This analysis indicates that the top-bank width can be expected to increase about $6 \mathrm{ft}$ at the cross section located $75 \mathrm{ft}$ upstream of U.S. Highway 82. Top-bank width can be expected to increase about $20 \mathrm{ft}$ at the cross section located about $100 \mathrm{ft}$ downstream of the highway crossing and about $9 \mathrm{ft}$ at the cross section located about $500 \mathrm{ft}$ downstream of the crossing. On the basis of the current rate of bank retreat, much of the projected channel widening may occur in the next 5 to 10 years. However, destructive flooding can affect these projections.

\section{CONCLUSIONS}

The channel of the Big Black River Canal tributary at U.S. Highway 82 at Stewart, Miss., has degraded about $8 / 2 \mathrm{ft}$ since 1936 and continues to respond to the degradation of the Big Black River Canal that was excavated in about 1928. About $1 / 2 \mathrm{ft}$ of further degradation through the year 2010 could reasonably be expected on the canal at the mouth of the tributary and on the tributary in the vicinity of U.S. Highway 82 . The channel top-bank width of the tributary $100 \mathrm{ft}$ downstream of U.S. Highway 82 is expected to increase about $20 \mathrm{ft}$ in the next 5 to 10 years if the present rate of widening continues. These projections are based on the assumption that no additional channel modifications and no unusually large and destructive flooding will occur by the year 2010 . 


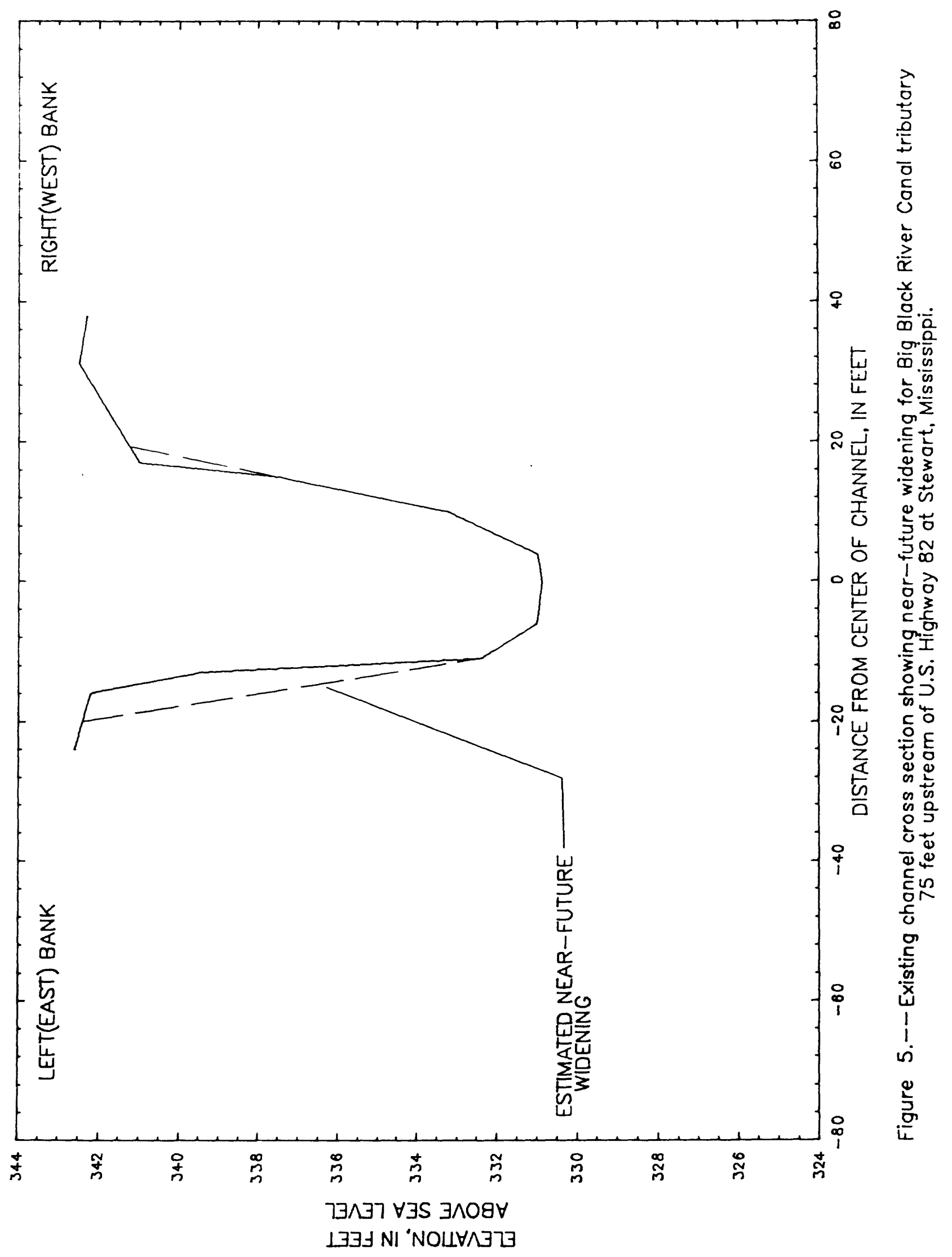




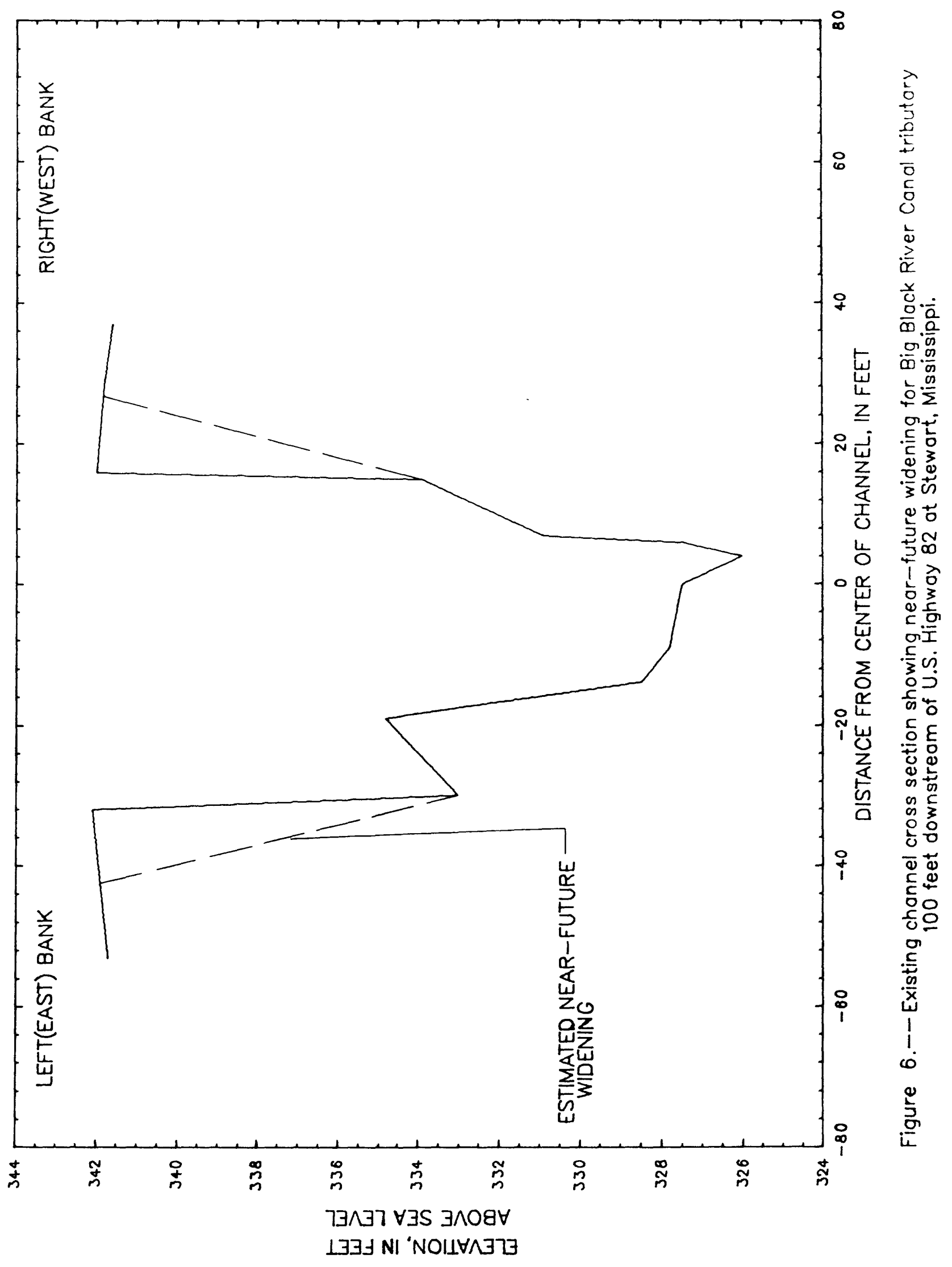




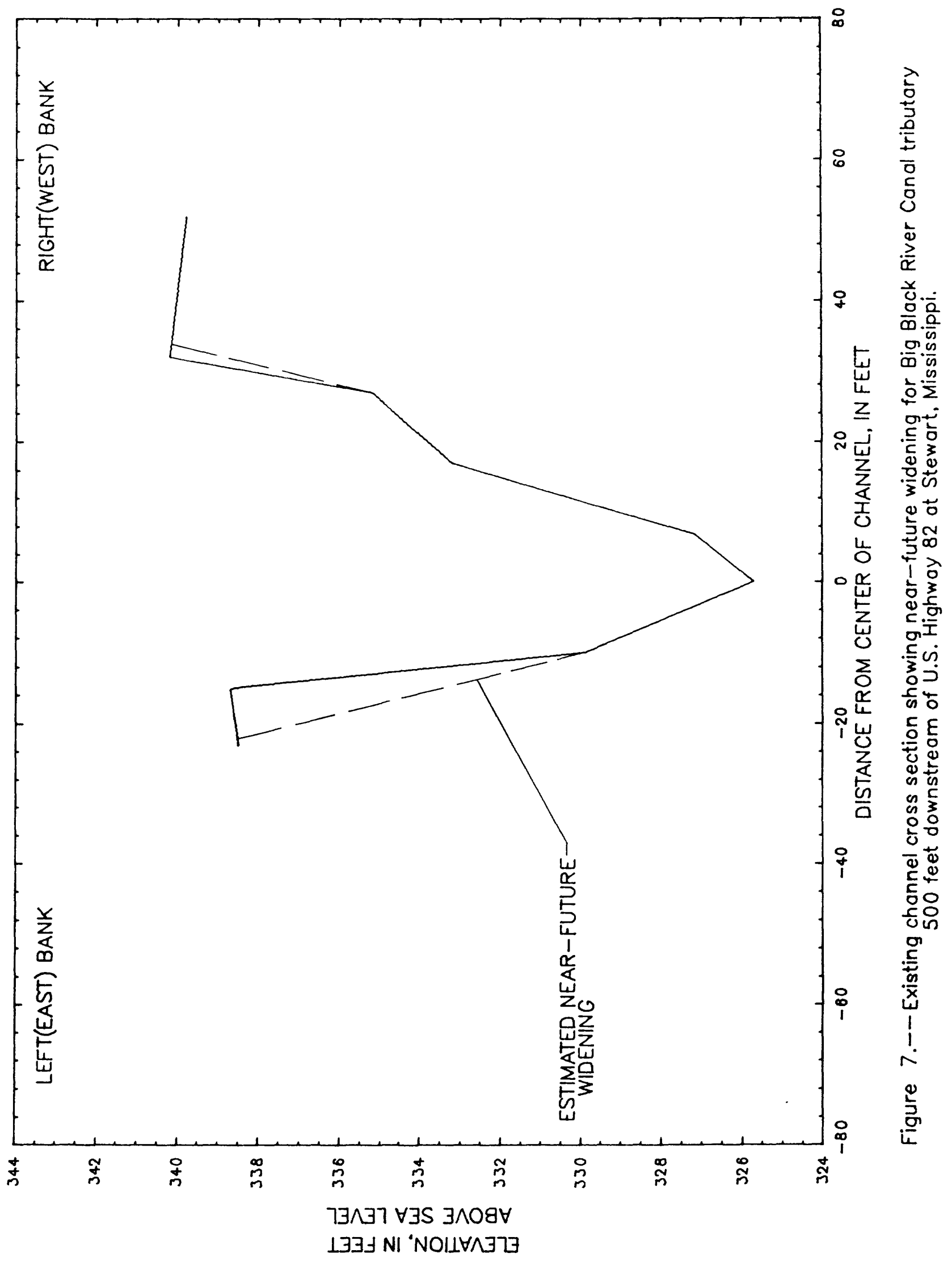




\section{REFERENCES}

Cernica, J.N., 1982, Geotechnical engineering: CBS College Publishing, $488 \mathrm{p}$.

Das, B.M., 1984, Principles of foundation engineering: Wadsworth, Inc., $595 \mathrm{p}$.

Handy, R.L., 1981, Borehole shear test, instructions version 9-81: Ames, Iowa, Handy Geotechnical Instruments, Inc., $26 \mathrm{p}$.

Handy, R.L., and Fox, N.W., 1967, A soil bore-hole direct-shear device: Highway Research News No. 27, p. 42-51.

Huang, Y.H., 1983, Stability analysis of earth slopes: Van Nostrand and Co., $305 \mathrm{p}$.

Hupp, C.R., 1987, Determination of bank widening and accretion rates and vegetation recovery along modified West Tennessee streams, in International Symposium Proceedings of Ecological Aspects of Tree-Ring Analysis: Department of Energy conference-8608144, p. 224233.

Sigafoos, R.S., 1964, Botanical evidence of floods and floodplain deposition: U.S. Geological Survey Professional Paper 485-A, p. A1-A33.

Simon, Andrew, and Hupp, C.R., 1986a, Channel widening characteristics and bank slope development along a reach of Cane Creek, West Tennessee, in Subitzki, Seymour, ed., Selected papers in the hydrologic sciences: U.S. Geological Survey Water-Supply Paper 2290, p. 113126. -1986b, Channel evolution in modified Tennessee channels: Proceedings 4th Inter-Agency Sedimentation Conference, Las Vegas.

Sowers, G.F., 1979, Introductory soil mechanics and foundations: Geotechnical engineering (4th ed.): MacMillan Publishing Co., Inc., $621 \mathrm{p}$.

Spangler, M.G., and Handy, R.L., 1973, Soil Engineering (3rd ed.): New York and London, Intext Educational, $748 \mathrm{p}$.

Thorne, C.R., Murphey, J.B., and Little, W.C., 1981, Stream channel stability, Appendix D, Bank stability and bank material properties in the bluffline streams of northwest Mississippi: Oxford, Miss., U.S. Department of Agriculture, Sedimentation Laboratory, $257 \mathrm{p}$.

U.S. Army Corps of Engineers, 1946, Hydraulics of Big Black River Channel improvements: U.S. Army Corps of Engineers, Vicksburg District, 9 p. 